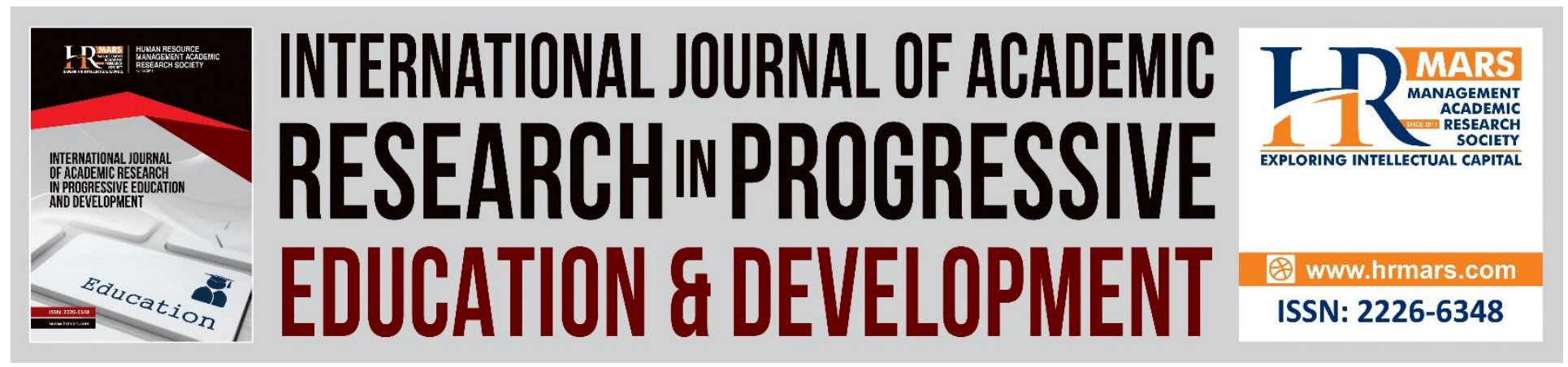

\title{
Availability, Utilization and Conservation of Teaching Facilities in Delta State Primary Schools
}

Ataine Juliet Asoro

To Link this Article: http://dx.doi.org/10.6007/IJARPED/v10-i1/8924

DOI:10.6007/IJARPED/v10-i1/8924

Received: 01 January 2021, Revised: 31 January 2021, Accepted: 17 February 2021

Published Online: 20 March 2021

In-Text Citation: (Asoro, 2021)

To Cite this Article: Asoro, A. J. (2021). Availability, Utilization and Conservation of Teaching Facilities in Delta State Primary Schools. International Journal of Academic Research in Business and Social Sciences, 10(1), 237-247.

Copyright: (C) 2021 The Author(s)

Published by Human Resource Management Academic Research Society (www.hrmars.com)

This article is published under the Creative Commons Attribution (CC BY 4.0) license. Anyone may reproduce, distribute, translate and create derivative works of this article (for both commercial and non-commercial purposes), subject to full attribution to the original publication and authors. The full terms of this license may be seen at: http://creativecommons.org/licences/by/4.0/legalcode

Vol. 10(1) 2021, Pg. 237 - 247

http://hrmars.com/index.php/pages/detail/IJARPED

JOURNAL HOMEPAGE

Full Terms \& Conditions of access and use can be found at http://hrmars.com/index.php/pages/detail/publication-ethics 


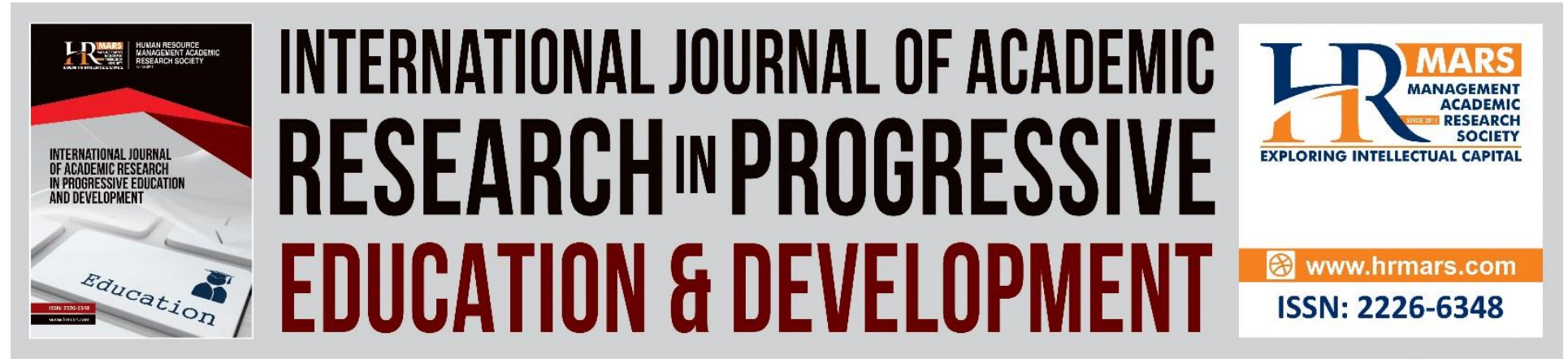

\title{
Availability, Utilization and Conservation of Teaching Facilities in Delta State Primary Schools
}

\author{
Ataine Juliet Asoro (PhD) \\ State Universal Primary Education Board \\ Email: ebruphiyo55@gmail.com
}

\begin{abstract}
This study analysed availability, utilization and conservation of teaching facilities in Delta State primary schools. It was a descriptive survey and adopted ex-post-facto design, with a population of 1,113 headmasters/headmistress in public primary schools in Delta State. A sample of 222 headmasters/headmistress were sampled using stratified sampling technique. Instrument titled Availability, Utilization and Conservation of Teaching Facilities Questionnaire (AUCTFQ) was used. Data was analysed using mean, standard deviation and ranking. Finding shows that administrative rooms, block of classrooms, visual aids, chairs, audio visual aids, water facilities, toilets, desks, tables, books, writing boards, playground and electricity were available but not all were utilized and conserved. It is thus recommended that government and well meaningful individual in the society should strive and ensure that all teaching facilities are made available in the school for the benefit of the pupils. Also, teaching facilities should be adequate such that it will be utilized by the pupils and teachers. From time to time, government should ensure that these teaching facilities are conserved to retain its original state.
\end{abstract}

Keywords: Availability, Utilization and Conservation of Teaching Facilities.

\section{Introduction}

In Nigeria, education is overseen by the Ministry of Education. Local authorities also take obligation for instigating policy for state controlled public education. Nigeria system of education is alienated into kindergarten, primary, secondary and tertiary education. However, the focus of this study is on primary education. Primary education is very important in the Nigerian education system. According to Oni (2009) it is the oldest system of education in Nigeria and a link between pre-primary secondary education. Primary school pupils are obligatory to take a joint entrance examination to meet the requirements for admission into federal or state owned secondary schools, private secondary schools inclusive. But more importantly, it is generally regarded as the very foundation upon which the other education is built on. Undermining the fact that preprimary education is a level below primary education, it is not considered as the foundation. This 
is because pre-primary education is mostly available in cities and enjoyed by few children whose parents could afford the high fees and other charges demanded by the private proprietors.

The anticipated successful implementation primary education will be anchored on the availability, utilization and conservation of teaching facilities. Teaching facilities are those material that aid teaching and learning thereby giving room for meaningful and purposeful learning. Teaching facilities are the total school plant which educators, administrators and pupil harness and utilized for effective and proficient management of educational process, in order to make for meaningful and focussed teaching and learning experience. Teaching facilities are much more than passive container of education process; it is rather an essential module of the conditions of learning. Any item which can be used to implement efforts in teaching is regarded as learning facilities (Amboningtyas, 2018). Facility design of contributes to the experience of the students, pupils, educators and even members of the community. Teaching facilities serve as pillars of support for actual teaching and learning. Good quality and standard of school depend largely on the availability, utilization and conservation of teaching facilities, based on this, effectiveness can only be realized if materials available are put to use. Therefore, teaching facilities are resources that facilitate effective and efficient teaching and learning. They include block of classrooms, library, toilets, administrative rooms, tables, desks, chairs, craft room, storage space, electricity, playground, visual and audio visual aids, writing boards, books, water facilities, teachers tools and consumables. These help to provide pupils friendly school environment that create conducive atmosphere for effective responsive teaching and learning experience. Discussion on implication of teaching facilities it was revealed that school plant planning is directly significant to students' academic performance. This means that students' academic performance could be related to administrative, instructional, circulation and space for convenience planning (Arowojolu et al., 2019). In the Nigerian context, teaching facilities are seriously limited, thus the need to encourage proper use and conservation of available facilities as much as possible. Teaching facilities conservation entails periodic renovation of buildings, servicing the school bus, servicing the generator sets, keeping the school sport field, playground and the entire school surrounding clean, it also involves general repairs in order to restore the facilities to optimal working condition.

In a study conducted by Akintola and Oyeboade (2009) on accessibility and use of library resources by undergraduate's students in Nigeria State University of Technology. Using a survey method, with population of library students in the institutions and sample of from 200 level to 500 level who use library resources. The questionnaires were distributed to 600 respondents that constituted the sample. Percentages and t-test statistics was used to analyse the data using the statistical package for social sciences (SPSS). The result of the study revealed that $63.1 \%$ respondents were male undergraduates while $39.9 \%$ of the respondents were female students. The result of the study also shows that greater percentage (63.1\%) of the respondents had access to computer while lesser percentage (36.9\%) of the respondents did not have access to computer. Ikoya (2008) discovered that decentralization enhances the availability, adequacy and functionality of school Physical Education facilities in Edo State. To support the findings of Ikoya, Tadesse (2014) result showed that the availability of teaching facilities and instructional materials were unavailable, less in quantity and quality that created a great challenge on teaching and learning activities that in turn had a negative impact on the improvement of the quality of 
education. There are indications that teaching facilities such as typewriters, computers, projectors recorders, internet facilities scanning machines, and electronic smart boards are not sufficiently provided (Boma 2019). In a similar study, Onu and Ezhim (2019) discovered that some teaching and ICT facilities are not provided, and few provided ones were not used as a result of non-functionality.

Akinfolarin (2015) observed challenges on inadequate and non-availability of physical resources which are likely to result into unfavourable climate in Vocational and Technical Education, South West Colleges of Education, Nigeria. The study result shows that most of the required resources in were available in Vocational and Technical Education with exception to Departments of Business Studies where some of the required resources were not available. The study also shows that resources available in Agricultural Science Department and Technical Education were not fully utilized in South West Colleges of Education. This may be the reason Ede and Olaitan (2010) revealed a large number of ICT tools up to 27 ICT tools were not utilized in South West, Nigeria. Learning facilities have optimistic and significant result on vocational productivity in school (Sobandi et. al., 2020).

In Ibarapa North LGA, Oyo State Ogundiran (2015) examined instructional materials' availability and Utilization: implications on public primary School students' academic performance. A survey design was adopted for the study. Data were collected from 320 primarysix pupils and 137 teachers randomly selected through stratified technique in Ibarapa North Local Government Area. Four research questions guided the study. Description statistics adopted in the study revealed that primary six pupils accepted that instructional materials are underutilized in Ibarapa North LGA due to inefficiency and poor quality of teachers who were products of N.T.I who cannot utilize instructional resources effectively. Findings of Ugwuanyi (2013) specified that of all physical education teaching facilities only soccer fields are available in all the schools. However more than half of the schools have volleyball courts, basketball courts and athletic tracks and fields. On equipment and supplies of physical education only whistles are available in all the schools studied; other items that are available in some of the schools include soccer balls, etc. This finding indicates that facilities for physical education, equipment and supplies, field was the only item which was adequate in the schools. In M-university, facilities for teaching particularly e-learning were adequate and reachable to users. It was also discovered that the teachers were comfortable with the rate of utilisation of several facilities throughout classes compared to some public institutions even when the utilisation has not reached apex (Eze, Chinedu-Eze, \& Bello 2018).

Teaching facilities conservation refers to the keeping of teaching facilities such as buildings, equipment near their original state of utility as much as possible. Onoyase (2013) is of the opinion that it is a common knowledge that as soon as teachers, pupils, administrators and technical staff begin to function in the areas specifically designed for them, facilities such as building, equipment and machinery are said to be operational. This is the stage in the life of the facilities when aging process sets in. The materials, equipment and surface of the buildings start to deteriorate slowly and in fact each part of the mechanical equipment starts to wear out. The aging process is natural and applies to all teaching facilities. The aging process cannot be eliminated nor avoided, that is why programme of conservation is taken as an integral part of the daily operation of teaching facilities. 
Facilities tend to depreciate as soon as they are provided and put into use. Thus, the need for conservation via repairs or servicing components to restore their educational condition and sustained their working capacity. One of the fundamental ways of ensuring the optimum utility of available teaching facilities is through conservation culture. Akpan (2013) opined that the general appearance of teaching facilities constitutes the basis upon which members of the public pass their judgement about the academic performance going on in the school. It follows that conservation culture of any school speaks much about such institution. Olaleye (2013) noted that over the last two decades, the management of primary schools have been experiencing some problems as a result of policy gaps in Nigeria. Schools were not well conserved and facilities were not adequately provided arising from the facts that management of primary education were used as political football between State government, local government and federal government. Having this in mind, it therefore becomes essential for school administrators to take conservation of the few available facilities as a priority. When facilities are not conserved, they deteriorate and wear out faster than their normal life span, hence they become less to nonexistence.

Conservation of facilities entails keeping the school sports and football field clean, servicing of the generator sets, periodic renovation of buildings and other repairs for the purpose of restoring the facilities to optimum working condition. When facilities are not well conserved, they constitute threat to life of pupils and teachers who use them. It is on this view that Akpan (2013) asserted that the worst of our woes is the conservation of school building or facilities. Millions of naira can waste away if teaching facilities are not properly conserved. The health of pupils may be in continuous peril when the convince are not hygiene, and when walls are about to fall, life will be threatened. When school walls/roofs collapsed, teachers and pupils were killed (Asiyai, 2006). Equipment worth thousands of naira must have been destroyed in the process. More so. Large amount of money will be expended in rebuilding the walls and reroofing. Conservation enhances performance and durability; it also prevents wastage. Therefore, the key to the protection of our teaching facilities is proper planning today and the commitment to conservation and operations thereafter. Uchendu, et. al., (2013) suggested that proper management of teaching facilities in schools.

\section{Statement to the Problem}

Educational sector in Nigeria are confronted with problems which often hampers the realisation of set goals and objectives. The productivity of any public primary schools depend largely on availability, utilization and conservation of teaching facilities for success to be achieved. The researcher observed and interactions with teachers have revealed that most primary schools in Delta State are in state of mercy even when its acclaimed that the governor has fixed all the primary schools with modern facilities. But most schools have dilapidated buildings with leaking roofs, rough floors, cracked walls, shortage of teaching and learning spaces, windows without louvers, broken chairs and desk, bushy compounds, dirty buildings without light, even toilets of most schools have collapsed beyond repair, while most do not have toilet at all. There is neither water reservoir, nor borehole water in most of the schools, not even talk about library and even when they exist, it has not been in use. There is no doubt saying that there is complete lack or neglect for teaching facilities in schools. Also teachers are accused by government and other stakeholders of not being conscientious of their work in respect of use and conservation of 
teaching facilities to bring about the achievement of educational goals. Teachers on their own pour blame on government and stakeholders in education for not providing the necessary teaching facilities that would bring about desired educational goals. But it is well known to most individuals that if the educational goals and objectives are to be achieved, then adequate teaching facilities must be provided. Poorly equipped school could strife the implementation of school curriculum. Teaching facilities in schools are regarded as the emblem of beauty of the school, so to neglect the provision of teaching facilities is to neglect education totally and all it stands for. The purpose of this study is to identify teaching facilities available, utilized and conserved in Delta State primary schools.

\section{Research Questions}

1. What are the available teaching facilities in primary schools?

2. Which of teaching facilities are being utilized in primary schools?

3. Which of these teaching facilities are being conserved in primary schools?

\section{Method}

The study is a descriptive survey adopting ex-post-facto designed to analyse availability, utilization and conservation of teaching facilities. The population of the study consist of 1,113 public primary schools in the three senatorial districts in Delta State, with 1,113 headmasters/headmistress in public primary schools in Delta State as at 2019/2020 academic year. A sample of 222 headmasters/headmistress were sampled using stratified random sampling technique. The instrument to be used for the study is a self-developed questionnaire titled Availability, Utilization and Conservation of Teaching Facilities Questionnaire (AUCTFQ), divided in two sections and validated through experts' judgement. The instrument was further subjected to spilt-half reliability test using 20 respondents excluded from the main study and a co-efficient of .77 was obtained showing a high reliability index. Data collected was analysed using mean, standard deviation and ranking to answer research questions. 
INTERNATIONAL JOURNAL OF ACADEMIC RESEARCH IN PROGRESSIVE EDUCATION AND DEVELOPMENT

Vol. 10, No. 1, 2021, E-ISSN: $2226-6348 @ 2021$ HRMARS

Presentation of Results and Discussion

Research Question 1: What are the available teaching facilities in primary schools?

Table 1: Analysis on available teaching facilities in primary schools

\begin{tabular}{|c|l|c|l|l|l|}
\hline S/N & Available Teaching Facilities & Mean & SD & Rank & Decision \\
\hline 1. & Administrative rooms & 3.10 & .78 & $1^{\text {st }}$ & Available \\
\hline 2. & Block of classrooms & 3.06 & .83 & $2^{\text {nd }}$ & Available \\
\hline 3. & Visual aids & 3.05 & .81 & $3^{\text {rd }}$ & Available \\
\hline 4. & Chairs & 3.02 & .83 & $4^{\text {th }}$ & Available \\
\hline 5. & Audio visual aids & 3.02 & .83 & $5^{\text {th }}$ & Available \\
\hline 6. & Water facilities & 3.00 & .82 & $6^{\text {th }}$ & Available \\
\hline 7. & Toilets & 2.97 & .81 & $7^{\text {th }}$ & Available \\
\hline 8. & Desks & 2.97 & .82 & $8^{\text {th }}$ & Available \\
\hline 9. & Tables & 2.94 & .82 & $9^{\text {th }}$ & Available \\
\hline 10. & Books & 2.93 & .84 & $10^{\text {th }}$ & Available \\
\hline 11. & Writing boards & 2.92 & .82 & $11^{\text {th }}$ & Available \\
\hline 12. & Playground & 2.77 & .85 & $12^{\text {th }}$ & Available \\
\hline 13. & Electricity & 2.76 & .84 & $13^{\text {th }}$ & Available \\
\hline 14. & Library & 2.46 & .80 & $14^{\text {th }}$ & Not Available \\
\hline 15. & Consumables & 2.45 & .83 & $15^{\text {th }}$ & Not Available \\
\hline 16. & Storage space & 2.11 & .80 & $16^{\text {th }}$ & Not Available \\
\hline 17. & Teachers' tools & 2.05 & .83 & $17^{\text {th }}$ & Not Available \\
\hline 18. & Craft room & 2.01 & .79 & $18^{\text {th }}$ & Not Available \\
\hline
\end{tabular}

Data in Table 1 shows analysis of available teaching facilities in primary school. Results revealed that administrative rooms, block of classrooms, visual aids, chairs, audio visual aids, water facilities, toilets, desks, tables, books, writing boards, playground and electricity were available with mean scores above 2.50 and ranked $1^{\text {st }}-13^{\text {th }}$. Also, library, consumables, storage space, teachers' tools and craft room were not available with mean scores less than 2.50 and ranked $14^{\text {th }}-18^{\text {th }}$. Thus not all teaching facilities are available in primary schools. This finding is in agreement with Ikoya (2008) who discovered that decentralization enhances the availability, adequacy and functionality of school Physical Education facilities in Edo State. Tadesse (2014) result showed that the availability of teaching facilities and instructional materials were unavailable, less in quantity and quality that created a great challenge on teaching and learning activities that in turn had a negative impact on the improvement of the quality of education. Akinfolarin (2015) who observed challenges on inadequate and non-availability of physical resources which are likely to result into unfavourable climate in Vocational and Technical Education, South West Colleges of Education, Nigeria. The study result shows that most of the required resources in were available in Vocational and Technical Education with exception to Departments of Business Studies where some of the required resources were not available. 
INTERNATIONAL JOURNAL OF ACADEMIC RESEARCH IN PROGRESSIVE EDUCATION AND DEVELOPMENT

Vol. 10, No. 1, 2021, E-ISSN: 2226-6348 @ 2021 HRMARS

Research Question 2: Which of teaching facilities are being utilized in primary schools?

Table 2: Analysis on teaching facilities utilized in primary schools

\begin{tabular}{|c|l|c|l|l|l|}
\hline S/N & Utilization of Teaching Facilities & Mean & SD & Rank & Decision \\
\hline 1. & Playground & 3.07 & .83 & $1^{\text {st }}$ & Utilized \\
\hline 2. & Books & 3.04 & .87 & $2^{\text {nd }}$ & Utilized \\
\hline 3. & Tables & 3.03 & .82 & $3^{\text {rd }}$ & Utilized \\
\hline 4. & Desks & 3.01 & .80 & $4^{\text {th }}$ & Utilized \\
\hline 5. & Writing boards & 3.00 & .84 & $5^{\text {th }}$ & Utilized \\
\hline 6. & Administrative rooms & 2.98 & .83 & $6^{\text {th }}$ & Utilized \\
\hline 7. & Chairs & 2.94 & .82 & $7^{\text {th }}$ & Utilized \\
\hline 8. & Block of classrooms & 2.90 & .82 & $8^{\text {th }}$ & Utilized \\
\hline 9. & Toilets & 2.90 & .83 & $9^{\text {th }}$ & Utilized \\
\hline 10. & Consumables & 2.35 & .84 & $10^{\text {th }}$ & Not Utilized \\
\hline 11. & Teachers' tools & 2.33 & .82 & $11^{\text {th }}$ & Not Utilized \\
\hline 12. & Craft room & 2.28 & .81 & $12^{\text {th }}$ & Not Utilized \\
\hline 13. & Visual aids & 2.19 & .83 & $13^{\text {th }}$ & Not Utilized \\
\hline 14. & Water facilities & 2.05 & .77 & $14^{\text {th }}$ & Not Utilized \\
\hline 15. & Library & 2.00 & .81 & $15^{\text {th }}$ & Not Utilized \\
\hline 16. & Storage space & 1.98 & .82 & $16^{\text {th }}$ & Not Utilized \\
\hline 17. & Audio visual aids & 1.96 & .83 & $17^{\text {th }}$ & Not Utilized \\
\hline 18. & Electricity & .86 & $18^{\text {th }}$ & Not Utilized \\
\hline
\end{tabular}

Data in Table 2 shows analysis of teaching facilities utilized in primary school. Results revealed that playground, books, tables, desks, writing boards, administrative rooms, chairs, block of classrooms and toilets were utilized with mean scores above 2.50 and ranked between $1^{\text {st }}$ to $9^{\text {th }}$ position. While consumables, teachers' tools, craft room, visual aids, water facilities, library, storage space, audio visual aids and electricity were not utilized with mean scores below 2.50 and ranked between $10^{\text {th }}$ and $18^{\text {th }}$ position. This finding supports Ede and Olaitan (2010) revealed a large number of ICT tools up to 27 ICT tools were not utilized in South West, Nigeria. Ogundiran (2015) revealed that primary six pupils accepted that instructional materials are underutilized in Ibarapa North LGA due to inefficiency and poor quality of teachers who were products of N.T.I who cannot utilize instructional resources effectively. Ugwuanyi (2013) specified that of all physical education teaching facilities only soccer fields are available in all the schools. However more than half of the schools have volleyball courts, basketball courts and athletic tracks and fields. On equipment and supplies of physical education only whistles are available in all the schools studied; other items that are available in some of the schools include soccer balls, etc. This finding indicates that facilities for physical education, equipment and supplies, field was the only item which was adequate in the schools. 
INTERNATIONAL JOURNAL OF ACADEMIC RESEARCH IN PROGRESSIVE EDUCATION AND DEVELOPMENT

Vol. 10, No. 1, 2021, E-ISSN: 2226-6348 @ 2021 HRMARS

Research Question 3: Which of these teaching facilities are being conserved in primary schools? Table 3: Analysis on teaching facilities conservation in primary schools

\begin{tabular}{|c|l|r|r|l|l|}
\hline S/N & Conservation of Teaching Facilities & Mean & SD & Rank & Decision \\
\hline 1. & Books & 3.03 & .82 & $1^{\text {st }}$ & Conserved \\
\hline 2. & Toilets & 3.03 & .85 & $2^{\text {nd }}$ & Conserved \\
\hline 3. & Administrative rooms & 3.02 & .77 & $3^{\text {rd }}$ & Conserved \\
\hline 4. & Writing boards & 2.99 & .79 & $4^{\text {th }}$ & Conserved \\
\hline 5. & Block of classrooms & 2.96 & .81 & $5^{\text {th }}$ & Conserved \\
\hline 6. & Playground & 2.95 & .82 & $6^{\text {th }}$ & Conserved \\
\hline 7. & Tables & 2.93 & .80 & $7^{\text {th }}$ & Not Conserved \\
\hline 8. & Teachers' tools & 2.19 & .77 & $8^{\text {th }}$ & Not Conserved \\
\hline 9. & Electricity & 2.13 & .84 & $9^{\text {th }}$ & Not Conserved \\
\hline 10. & Consumables & 2.13 & .77 & $10^{\text {th }}$ & Not Conserved \\
\hline 11. & Water facilities & 2.04 & .77 & $11^{\text {th }}$ & Not Conserved \\
\hline 12. & Library & 2.03 & .77 & $12^{\text {th }}$ & Not Conserved \\
\hline 13. & Audio visual aids & 2.00 & .77 & $13^{\text {th }}$ & Not Conserved \\
\hline 14. & Visual aids & 1.99 & .77 & $14^{\text {th }}$ & Not Conserved \\
\hline 15. & Desks & 1.98 & .76 & $15^{\text {th }}$ & Not Conserved \\
\hline 16. & Craft room & 1.94 & .83 & $16^{\text {th }}$ & Not Conserved \\
\hline 17. & Storage space & 1.92 & .83 & $17^{\text {th }}$ & Not Conserved \\
\hline 18. & Chairs & 1.89 & .82 & $18^{\text {th }}$ & Not Conserved \\
\hline
\end{tabular}

Data in Table 3 shows analysis of teaching facilities conservation in primary school. Results revealed that books, toilets, administrative rooms, writing boards, block of classrooms and playground were conserved with mean scores of 2.50 and above and ranked $1^{\text {st }}-6^{\text {th }}$. While tables, teachers' tools, electricity, consumables, water facilities, library, audio visual aids, visual aids, desks, craft room, storage space and chairs were not conserved with mean scores less than 2.50 and ranked $7^{\text {th }}-18^{\text {th }}$. This implies that some teaching facilities such as books, toilets, administrative rooms, writing boards, block of classrooms and playground are conserved while tables, teachers' tools, electricity, consumables, water facilities, library, audio visual aids, visual aids, desks, craft room, storage space and chairs are not conserved. This finding is in line with Onoyase (2013) who revealed that it is a common knowledge that as soon as teachers, pupils, administrators and technical staff begin to function in the areas specifically designed for them, facilities such as building, equipment and machinery are said to be operational. Akpan (2013) who discovered that the general appearance of teaching facilities constitutes the basis upon which members of the public pass their judgement about the academic performance going on in the school. It follows that conservation culture of any school speaks much about such institution. Olaleye (2013) who revealed that schools were not well conserved and facilities were not adequately provided arising from the facts that management of primary education were used as political football between State government, local government and federal government. Uchendu, et. al., (2013) suggested that proper management of teaching facilities in schools. 


\section{Conclusion and Recommendations}

Teaching facilities are essential in the education of a child, lack of it, will result to lack of required knowledge transfer to the child. Some teaching facilities such as administrative rooms, block of classrooms, visual aids, chairs, audio visual aids, water facilities, toilets, desks, tables, books, writing boards, playground and electricity are available in Delta State primary school. The problem remains that some of these available teaching facilities are not adequately utilized due to it shortfall. Consequently, conservation of these teaching facilities remains a nightmare as broken chairs and desks were found within some classes and around the school. Although government are making efforts to conserve these teaching facilities but tables, teachers' tools, electricity, consumables, water facilities, library, audio visual aids, visual aids, desks, craft room, storage space and chairs are yet to be attended to. It is thus recommended that government and well meaningful individual in the society should strive and ensure that all teaching facilities are made available in the school for the benefit of the pupils. Also, teaching facilities should be adequate such that it will be utilized by the pupils and teachers. From time to time, government should ensure that these teaching facilities are conserved to retain its original state.

\section{References}

Akinfolarin, C. A. (2015). Organizational climate and physical resource utilization in vocational and technical education in colleges of education in South West Nigeria. International Journal of Educational Policy Research and Review, 2(1), 8-16.

Akintola, L., \& Oyeboade, S.A. (2009). Library philosophy and practice. An empirical study of accessibility and use of library resources by undergraduates in Nigerian state University of Technology. University of technology Ogbomoso, Oyo state Nigeria.

Akpan, C. (2013). Resource Management and Job Involvement among University Lecturers in South - South Nigeria. European Journal of Business and Social Sciences, 1(8), 12-22.

Amboningtyas, D. (2018). Influence of learning discipline, methods of teaching teachers and school facilities on improving student achievement in SMK Negeri 1 Pringapus. Journal of Management, 4(4).

Arowojolu, M. I., Yinusa, S. T., Ameh, F. A., Arowojolu, T. A. (2019). School Plants Planning and Maintenance as Correlate Students' Academic Performance in Irele Local Government Area of Ondo State, Nigeria. Education Journal, 9(5): 87-92, 10.5923/j.edu.20190905.02

Asiyai, R. I. (2006). An Appraisal of the Adequacy of the Physical Resources Availability for Teaching Chemistry in Secondary School in Delta State. Science Teaches Association of Nigeria. Proceedings of 47th Annual Conference 2006, Heinemann Education Book (Nig) plc.

Boma, P. B. (2019). Availability of Instructional Facilities in Teaching and Learning in Business Education Department in Rivers State University, International Journal of Innovative Education Research 7(2):1-11.

Ede, E.O. \& Olaitan, O.O. (2010). The Utilization of Information and Communication Technology (ICT) in quality assurance of technical college graduates in South-western states of Nigeria. Nigerian Vocational Journal, 14(2). 
INTERNATIONAL JOURNAL OF ACADEMIC RESEARCH IN PROGRESSIVE EDUCATION AND

DEVELOPMENT

Vol. 10, No. 1, 2021, E-ISSN: 2226-6348 @ 2021 HRMARS

Eze, S. C., Chinedu-Eze, V. C., and Bello, A. O. (2018). The utilisation of e-learning facilities in the educational delivery system of Nigeria: a study of M-University. International Journal of Educational Technology in Higher Education, 15:34, doi.org/10.1186/s41239-018-0116-z

Ikoya, P. O. (2008) Current Issues in Educational Management: Being a Tracing Programme organized by Delta State Universal Basic Education Board for Principals, Vice Principals and Counselor of Juniors Secondary Schools in Educational Management, Abraka. EDSERVE CONSULT (41 - 46).

Ogundiran, S. O. (2015). Instructional materials' availability and Utilization: implications on public primary School students' academic performance in Ibarapa North Local Government Area of Oyo State. Journal of Educational Review, 8(1), 71-80.

Olaleye, F. O. (2013). Management competencies, need for effective professionalization of Nigeria secondary school principals. Kuwait. Chapter of Arabian Journal of Business and Management review, 2(10): 49-54.

Oni, J. O. (2009). Management of Primary Education in Nigeria: Trends, Constraints and Solutions. Medwell Journal of Social Sciences, 4(3), 286-290.

Onoyase, D. (2013). Theory and practice of educational; Administration. Johnny \& Co., Warri, Nigeria.

Onu, F. M., and Eehim, I. A. (2019). Utilization of ICT Facilities for Enhancing Instructional Delivery of Agricultural Science in Nigerian Secondary Schools. Library Philosophy and Practice (ejournal). 2646. https://digitalcommons.unl.edu/libphilprac/2646

Sobandi, A., Yuniarsih, T., and Adman, R. (2020). Learning Facilities: Can It Improve the Vocational School Productivity? Journal of Educational and Social Research, 10(4), 146-155 www.richtmann.org, doi.org/10.36941/jesr-2020-0074

Tadesse, H. A. (2014). The availability of school facilities and their effects on the quality of education in government primary schools of Harari Regional State and East Hararghe Zone, Ethiopia. Middle Eastern \& African Journal of Educational Research, 11, 59-71.

Uchendu, C. C., Ekanem, E. E., and Jonah, S. T. (2013). Resource maintenance for the provision of educational services in public and private secondary schools in River State, Nigeria. European Journal of business and Social Sciences, 2(1): 15-23.

Ugwuanyi, J. I. (2013). Availability, adequacy and utilization of physical education teaching resources in secondary schools in Enugu State. Unpublished M.Ed. Dissertation, University of Nigeria, Nsukka. 